\title{
Home Range - Body Mass Allometry in Rabbits and Hares (Leporidae)
}

\author{
Robert K. SWIHART
}

\begin{abstract}
Swihart R. K. 1986: Home range-body mass allometry in rabbits and hares (Leporidae). Acta theriol., 30, 11: 139-148 [With 1 Table \& 1 Fig.].

Data for 12 species of leporids (rabbits and hares) indicates that home range size scales allometrically with body mass and is considerably influenced by the positive association between body mass and $S$, and index of home range overlap. Furthermore, the average area available per conspecific appears to be related to its energy requirements. Because behavioral ecology is a key determinant of home range size in many mammals, comparative studies must consider effects of conspecific interactions and habitat differences on individual space use patterns and home range size.

[Museum of Natur. History and Dept. of Syst. and Ecol., Univ. Kansas, Lawrence, Kansas 66045, USA]
\end{abstract}

\section{INTRODUCTION}

Home range size $(H)$ scales with body mass $(M)$ allometrically as $H=a M^{b}$ for lizards (Turner et al., 1969), birds (Schoener, 1968), and mammals (McNab, 1963; Harestad \& Bunnell, 1979). Mammalian basal metabolic rate $(B M R)$ also scales with body mass as $B M R=$ á $M^{0.75}$ (Kleiber, 1975), and recent evidence suggests that total daily energetic expenditures of mammals scale with body mass raised to approximately the same power (Garland, 1983). Thus, a focal issue in studies of home range scaling is whether home range size is energetically determined. A value near 0.75 for $b$ in the previous equation is expected if body-size energetics govern home range size.

Recently, an investigation of home range scaling in mammals was undertaken by Harestad and Bunnell (1979). They found that some trophic groups displayed home range-body mass exponents significantly larger than 0.75 . In particular, they found that $H=0.002 M^{1.02}$ best described the relationship between home range size and body mass for 27 species of herbivores, suggesting that with increasing body mass, home range size of primary consumers increased beyond values predicted from body-size energetics. To explain this discrepancy in home range scaling and metabolic rate scaling, they reasoned that body size and perceived habitat productivity were inversely correlated in herbivores. That is, home ranges of large herbivores encompass relatively greater 
amounts of unproductive habitat than home ranges of small herbivores, the net result being less usable energy per unit area for larger species. They argued that such a situation might result because large mammals with large energy requirements must travel among several food patches, whereas a single patch might fulfill the needs of a smaller mammal.

The Harestad-Bunnell model implicitly assumes that home range overlap is independent of body size among species (Damuth, 1981). As pointed out by Damuth (1981), a positive association between overlap and body size indicates an increase in energy used per unit area and thus a decline in the strength of Harestad and Bunnell's (1979) body mass-perceived habitat productivity relationship. Using an index of home range overlap (see Methods), Damuth (1981) reanalyzed the data from Harestad and Bunnell (1979) and found that a positive correlation existed between body size and overlap. This correlation caused him to question the importance of the body mass-perceived habitat productivity relation.

Although Damuth's findings are enlightening, his analysis relied upon data from several orders of mammals. A positive relationship between home range overlap and body mass has not yet been demonstrated in species with closer phylogenetic ties and similar digestive strategies. In this paper, I examine home range-body mass relations of the mammalian family Leporidae (rabbits and hares) with regard to the importance of overlap as a factor influencing home range size.

Leporids are ideal herbivores for investigating the disparate interpretations described above because species within this order share similar morphologies and digestive strategies, yet they exhibit a wide range of body masses, home range sizes, and population densities, and social organization ranges from territorial to colonial (Chapman \& Feldhamer, 1981; Myers \& Mykytowycz, 1958).

\section{METHODS}

Data on adult body mass, home range size, and population density $(D)$ of leporids were collected for 12 species comprising 3 genera (Table 1). Two species of pika (Ochotona) were included for comparative purposes. Body mass and home range values were averaged over both sexes to reduce differences resulting from sexual dimorphism. Numerous methods were used in computing $H$ and $D$, and this variability probably contributed to variability in the relationships examined. Part of this problem was reduced by using body masses of adults taken after the reproductive season and by using annual estimates of $H$ and $D$ when possible. To facilitate investigation of the effects of climatic factors on $H$, individual studies with estimates of both $H$ and $D$ were used when possible. If more than one study was needed to obtain the desired data for a given species, studies chosen were as geographically close together as possible. For the cottontail rabbits 
Table 1

Adult body mass, home range size, population density, and index of home range overlap (S) for 14 species of lagomorphs. Scientific names follow Honacki et al. (1982).

\begin{tabular}{|c|c|c|c|c|}
\hline Species a & $\begin{array}{l}\text { Body } \\
\text { mass, } \\
\text { g }\end{array}$ & $\begin{array}{l}\text { Home } \\
\text { range, } \\
\text { ha }\end{array}$ & $\begin{array}{l}\text { Population } \\
\text { density, } \\
\text { no./ha }\end{array}$ & $S$ \\
\hline Sylvilagus aquaticus ${ }^{1}$ (N) & 2235 & 4.4 & 0.4 & 1.8 \\
\hline S. aquaticus ${ }^{2}$ (S) & 1928 & 7.6 & 0.1 & 0.8 \\
\hline S. audubonii ${ }^{3}$ & 895 & 3.6 & 1.5 & 5.4 \\
\hline S. bachmani 4 & 641 & 0.4 & 0.9 & 0.4 \\
\hline S. floridanus 5 (N) & 1406 & 1.7 & 1.5 & 2.6 \\
\hline S. floridanus ${ }^{6}$ (M) & 1282 & 2.0 & 4.8 & 9.6 \\
\hline S. floridanus ${ }^{7}$ (S) & 1138 & 1.4 & 1.1 & 1.5 \\
\hline S. palustris ${ }^{8}$ & 1212 & 2.6 & 1.4 & 3.6 \\
\hline S. transitionalis ${ }^{9}$ & 951 & 0.4 & 3.1 & 1.2 \\
\hline Lepus alleni 10 & 3674 & 642.8 & 0.3 & 192.8 \\
\hline L. americanus ${ }^{11}$ & 1700 & 8.1 & $1.0^{\mathrm{b}}$ & 8.1 \\
\hline L. californicus ${ }^{12}$ & 2560 & 14.2 & 2.5 & 35.5 \\
\hline L. capensis ${ }^{13}$ & 3625 & 330.0 & 0.5 & 165.0 \\
\hline L. timidus $^{14}$ & 2822 & 18.5 & 1.2 & 22.2 \\
\hline Oryctolagus cuniculus ${ }^{15}$ & 1600 & 12.6 & 8.3 & 104.6 \\
\hline Ochotona collaris ${ }^{16}$ & 120 & $0.1^{\mathrm{c}}$ & 6.8 & 0.7 \\
\hline Ochotona princeps ${ }^{17}$ & 180 & 0.1 & 3.8 & 0.4 \\
\hline
\end{tabular}

a Letters in parentheses represent geographical subgroups for a species: $N=$ =northernmost latitude; $\mathrm{M}=$ middle latitude; $\mathrm{S}=$ southernmost latitude. $\mathrm{b}$ Estimate based on annual adult survivorship and spring density. c Home range estimate based on one individual.

Sources: 1 Terrel (1972); 2 Lowe (1958), ${ }^{3}$ Ingles (1941), Fitch (1947); ${ }^{4}$ Orr (1940), Connell (1954); 5 Allen (1939), Trent and Rongstad (1974); ${ }^{6}$ Fitzsimmons (1978); 7 Lowe (1958), Heard 1963); 8 Blair (1936), Carr (1939), Holler (pers. commun.); 9 Dalke (1942), Blymyer (1976); 10 Vohries and Taylor (1933), Madsen (1973); 11 Dolbeer and Clark (1975), Godin (1977); 12 Lechleitner (1958, 1959); ${ }^{13}$ Pielowski (1972); 14 Hewson (1968, 1977), Flux (1970), Watson and Hewson (1973), Watson et al. (1973); 15 Southern 1940); Southern and Thompson (1964), Lloyd (1977); 16 Rausch (1961), Broadbooks (1965); 17 Markham and Whicker (1973), Kawamichi (1976).

Sylvilagus aquaticus and $S$. floridanus, sufficient data were available to permit separation into latitudinally distinct subgroups.

An index of home range overlap, $S$, was calculated for each species (Table 1). $S$ represents the number of conspecifics occupying an area the size of the average individual's home range (i.e., $S=H \times D$; Damuth, 1981).

\section{RESULTS}

Home range size scaled allometrically with body mass in leporids (Fig. 1A) as $H=\left(1.9 \times 10^{-11}\right) M^{3.59}\left(R^{2}=0.77, P<0.005\right)$, and the scaling exponent differed significantly both from Harestad and Bunnell's exponent of $1.02(P<0.01)$ and from the exponent of 0.75 predicted by metabolic requirements $(P<0.01)$. 
Home range overlap (as estimated by $S$ ) was not independent of body mass in leporids either $\left[S=\left(1 \times 10^{-8}\right) M^{2.76} ; R^{2}=0.49, P<0.005\right]$. Mass-specific overlap was smallest in Sylvilagus aquaticus and largest in Oryctolagus cuniculus (Fig. 1B).
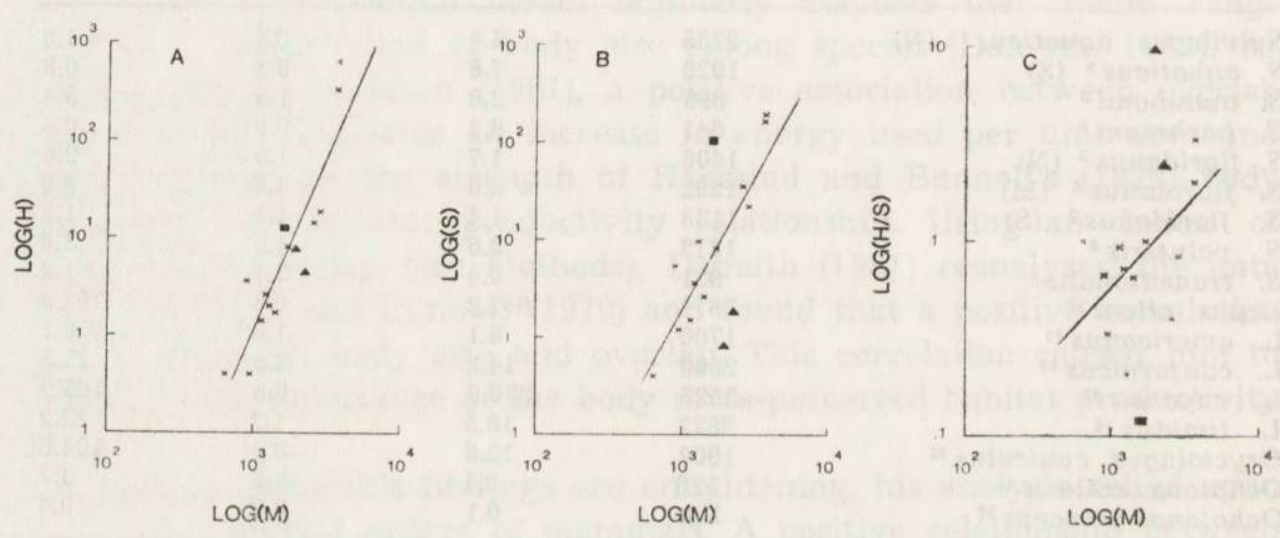

Fig. 1. Relationships between body mass (g) and: (A) home range size, $H$ (ha); (B) an index of home range overlap, $S$ (individuals per home range); (C) the area available per individual, $H / S$. Data were taken from Table 1 for 12 species of leporids and log-transformed (base 10) prior to regressions. Triangles depict Sylvilagus aquaticus; squares depict Oryctolagus cuniculus. See text for details regarding regression equations.

Because home range overlap increases as body mass increases, more individuals of large species use a given area within a home range relative to small species. Modification of the Harestad-Bunnell home range model to account for interspecific differences in overlap produces a model that may be expressed as $H / S=R / P$ (Damuth, 1981), where $R$ represents dialy energy requirements of an individual (i.e., $R=k M^{.075}$ ), $P$ is the daily production of usable energy supplied per hectare of habitat, and $H$ and $S$ are as defined earlier.

$H / S$, then provides a means of judging the relative influence of home range overlap and perceived habitat productivity on home range size. If $H / S=k M^{b}$, then home range overlap may be eliminated as a determinant of home range differences in leporids. Conversely, if $H / S=k M^{0.75}$, home range-body mass relationships can be explained using home range overlap, a measurable quantity, rather than relying on differences in species' perceptions of habitat patchiness (i.e., $P=k M^{0}$ ). For leporids, $H / S=k M^{{ }^{.083}}$. 


\section{DISCUSSION}

\section{Home Range Scaling}

Leporid home range sizes deviate substantially from home ranges predicted by body-size energetics $(b=3.59$ vs. 0.75). According to Harestad and Bunnell (1979), such a relationship could result because larger leporids (e.g., Lepus alleni, L. capensis) either encounter or use unproductive sites relatively more frequently than smaller leporids (e.g., Sylvilagus bachmani). This idea is intriguing, but detailed knowledge of the spatial distribution of resources as well as movement patterns of animals among and within resource patches is needed to test the hypothesis. Indeeed, some evidence (see references in Damuth, 1981) suggests that habitat patchiness may be greater in small mammal home ranges.

Furthermore, $S$ and $M$ are significantly correlated, thus violating the implicit assumption of the Harestad-Bunnell model that home range overlap and body mass are independent. In general, if $S<1$, some type of spacing behavior is implied. For instance, $S$ values for Ochotona were less than unity (Table 1), indicating that spaces occur between individual home ranges. These pikas are territorial (Broadbooks, 1965), and foraging activity is conducted along the periphery of the talus slopes they inhabit (Broadbooks, 1965; Bunnell \& Johnson, 1974). Thus, the spaces indicated by the low values in Table 1 may occur in centers of large slide areas that are not used for foraging.

Sylvilagus aquaticus exhibited much smaller $S$ values than expected (observed vs, expected $S$ values were $1.8 v s .17 .6$ for the northernmost subgroup and 0.8 vs. 11.7 for the southernmost subgroup). Cursorial ability is reduced in Sylvilagus relative to Lepus (Vaughan, 1972), hence one would expect $S$. aquaticus to exhibit a smaller home range than the comparably-sized L. californicus (Table 1). Also, S. aquaticus is the largest lagomorph in Table 1 that exhibits territorial behavior (Lowe, 1958; Marsden \& Holler, 1964), further contributing to the species' low $S$ value.

If large $S$ values are due primarily to high population densities, then sociality is predicted. Oryctolagus, a colonial species (Southern, 1940) exemplifies how social interactions result in considerable home range overlap (Table 1). Not surprisingly, solitary species of roughly the same body size as Oryctolagus (e.g., Sylvilagus floridanus, Lepus americanus) exhibited much smaller overlap values (Table 1).

Large $S$ values may be due to large home ranges, though. Sociality is less likely in this instance because large, economically undefendable 
home ranges promote considerable home range overlap without concomitant increases in the frequency of behavioral interactions. For example, Lepus spp. exhibit large $S$ values (Table 1), but individuals are primarily solitary and territorial defense undoubtedly is impractical in this wide-ranging genus.

$H / S$ provides an estimate of the area available per individual in a population. The similarity between the scaling factors for $H / S(0.83)$ and metabolic rate (0.75) suggests that after overlap is taken into account home range size is governed by body-size energetics and, by implication, that perceived habitat productivity $(P)$ is similar for large and small leporids. Unfortunately, these results cannot be considered entirely conclusive because despite the good fits provided by regressing $H$ and $S$ on body mass, the regression of $H / S$ on $M$ fits poorly $\left(R^{2}=0.09,0.10<\right.$ $<P<0.20$, Fig. 1C). It is interesting that the species deviating furthest from the regression line are the least (S. aquaticus) and most $(O$. cuniculus) social leporids (Fig. 1C). Mean home ranges for these two species agree closely with predicted home range sizes (Fig. 1A); due to their unique social structures, however, predicted $S$ values are either large underestimates $(O$. cuniculus) or overestimates (S. aquaticus) (Fig. 1B). Dividing $H$ by $S$, then, magnifies the importance of social organization in the space use of these species (Fig. 1C).

\section{Other Determinants of Home Range Size}

Although the analysis above suggests that examination of overlap and body mass is sufficient to explain home range scaling, this does not imply that other factors are unimportant in explaining differences in home range size among leporids. Namely, leporids with larger home ranges than predicted by body mass and overlap are usually associated with relatively unproductive environments, suggesting that net primary production is important. For example, L. alleni exhibits home ranges nearly twice as large as predicted by overlap and body mass and it lives in the hot, dry, semidesert regions of southern Arizona (Vohries and Taylor, 1933). Conversely, Oryctolagus cuniculus occupies smaller home ranges than predicted and inhabits farmland pastures and fields in the relatively mild climate of Great Britain (Southern, 1940). Productivity undoubtedly is an even more important determinant of home range size at the intraspecific level (e.g., Mares et al., 1982).

In addition to productivity, physiological time scaling of movements might play an important role in determining home range size (Lindstedt \& Calder, 1981; Calder, 1984). That is, small species may use a larger fraction of their home range per unit time relative to large species, resulting in a scaling exponent greater than 0.75 for the home range-body 
mass relationship (Lindstedt \& Calder, 1981). An estimate of this timescaling factor has been developed that takes into account an individual's pattern of home range use (Swihart \& Slade, 1985).

Because it is causally linked with so many ecological and life history characteristics (Blueweiss et al., 1978; Western, 1979; McNab, 1980; Lindstedt \& Calder, 1981; Swihart, 1984), body size is a central theme in the biology of organisms. It is not surprising, then, that body mass is the most important factor determining home range size in leporids. After body mass is taken into account, however, several facets of a species' ecology and surrounding environment may be useful in explaining the residual variation in home range size (Damuth, 1981; Lindstedt \& Calder, 1981; Mace \& Harvey, 1983). For rabbits and hares, home range overlap and possibly available primary productivity are important in this regard. In general, consideration of social organization, trophic status and foraging mode, primary productivity, and time scaling of movements is advisable when conducting interspecific comparisons of space use.

Acknowledgements. I am grateful to K. B. Armitage, J. Kozłowski, H. Levenson, J. R. Sauer, and N. A. Slade for their valuable input and constructive criticism of the manuscript. This work was conducted with the aid of an Honors Fellowship from the University of Kansas Graduate School. Computer time was provided by the University of Kansas Academic Computing Center.

\section{REFERENCES}

1. Allen D. L., 1939: Michigan cottontails in winter. J. Wildl. Manage., 3: 307-322.

2. Blair W. F., 1936: The Florida marsh rabbit. J. Mammal., 17: 197-207.

3. Blueweiss L., Fox H., Kudzma V., Nakashima D., Peters R., \& Sams S., 1978: Relationships between body size and some life history parameters. Oecologia, 37: $257-272$.

4. Blymyer M. J., 1976: A new elevation record for the New England cottontail (Sylvilagus transitionalis) in Virginia. Chesapeake Sci., 17: 220-221.

5. Broadbooks H. E., 1965: Ecology and distribution of the pikas of Washington and Alaska. Amer. Midland Natur., 73: 299-335.

6. Bunnell S. D. \& Johnson D. R., 1974: Physical factors affecting pika density and dispersal. J. Mammal., 55: 866-869.

7. Calder W. A. III, 1984: Size, function, and life history. Harvard Univ. Press: 1-431. Cambridge, Massachusetts.

8. Carr A. F. Jr., 1939: Notes on escape behavior in the Florida marsh rabbit. J. Mammal., 20: $322-325$.

9. Chapman J. A. \& Feldhamer G. A., 1981: Sylvilagus aquaticus. Mammalian Sp. No. 151: $1-4$.

10. Connell J. H. 1954: Home range and mobility of brush rabbits in California chaparral. J. Mammal., 35: 392-405.

11. Dalke P. D. 1942. The cottontail rabbits in Connecticut. Conn. State Geol. and Natur. Hist. Surv. Bull. No. 65: 1-97.

12. Damuth J. 1981: Home range, home range overlap, and species energy use among herbivorous mammals. Biol. J. Linn. Soc., 15: 185-193.

10 - Acta Theriologica 
13. Dolbeer R. A. \& Clark W. R., 1975: Population ecology of snowshoe hares in the central Rocky mountains. J. Wildl. Manage., 39: 535-549.

14. Fitch H. S. 1947: Ecology of a cottontail rabbit (Sylvilagus auduboni) population in central California. Calif. Fish and Game, 33: 159-184.

15. Fitzsimmons M. 1978: Influence of habitat on a west-central Indiana cottontail population. M. S. unpubl. thesis, Purdue Univ.

16. Flux J. E. C. 1970: Life history of the Mountain hare (Lepus timidus scoticus) in north-east Scotland. J. Zool., 161: 75-123.

17. Garland T. J., 1983: Scaling the ecological cost of transport to body mass in terrestrial mammals. Amer. Natur., 121: 571-587.

18. Godin A. J. 1977: Wild mammals of New England. John Hopkins Univ. Press: $1-304$. Baltimore.

19. Harestad A. S. \& Bunnell F. L., 1979: Home range and body weight - a reevaluation. Ecology 50: 389-402.

20. Heard L. P. 1963: Notes on cottontail rabbit studies in Mississippi. Proc. Conf. Southeast. Assoc. Game and Fish Comm. 17: 85-92.

21. Hewson R. 1968: Weights and growth rates in the mountain hare Lepus timidus scoticus. J. Zool., 154: 249-262.

22. Hewson R. 1977: Mountain hare Lepus timidus. [In: "The handbook of British mammals", 2nd edition, G. B. Corbet, H. N. Southern, Eds.]. Blackwell Sci. Publ: $144-150$. Oxford.

23. Honacki J. H. Kinman K. E. \& Koeppl J. W. (Eds.). 1982: Mammal species of the world. Allen Press: 1-694. Lawrence, Kansas.

24. Ingles L. G., 1941. Natural history observations on the Audubon cottontail. J. Mammal. 22: 227-250.

25. Kawamichi T. 1976. Hay territory and dominance rank of pikas (Ochotona princeps). J. Mammal., 57, 133-148.

26. Kleiber M. 1975: The fire of life. R. E. Krieger, New York.

27. Lechleitner R. R., 1958: Certain aspects of behavior of the black-tailed jackrabbit. Amer. Midland Natur., 60: 145-155.

28. Lechleitner R. R., 1959: Sex ratio, age classes and reproduction of the black-tailed jack rabbit. J. Mammal., 40: 63-81.

29. Lindstedt S. L. \& Calder W. A. III, 1981: Body size, physiological time, and longevity of homeothermic animals. Q. Rev. Biol., 56: 1-16.

30. Lloyd H. G., 1977: Rabbit Oryctolagus cuniculus. [In: "The handbook of British mammals", 2nd edition, G. B. Corbet, H. N. Southern, Eds.]. Blackwell Sci. Publ: 130-139. Oxford.

31. Lowe C. E. 1958: Ecology of the swamp rabbit in Georgia. J. Mammal., 39: $116-127$.

32. Mace G. M. \& Harvey P. H., 1983: Energetic constraints on home-range size. Amer. Natur., 121: 120-132.

33. Madsen R. L. 1973: Population studies of the desert cottontail (Sylvilagus auduboni), black-tailed jackrabbit (Lepus californicus), and Allen's jackrabbit (Lepus alleni) in the Sonoran desert. Arizona Coop. Wildl. Research Unit Quart. Report, 23: 3-4.

34. Mares M. A., Lacher T. E. Jr., Willig M. R., Bitar N. A., Adams R., Klinger A., \& Tazik D, 1982: An experimental analysis of social spacing in Tamias striatus. Ecology, 63: 267-273.

35. Markham O. D. \& Whicker F. W., 1973: Seasonal data on reproduction and body weights of pikas (Ochotona princeps). J. Mammal., 54: 496-498. 
36. Marsden H. M., \& Holler N. R., 1964: Social behavior in confined populations of the cottontail and the swamp rabbit. Wildl. Monogr., 13: 1-39.

37. McNab B. K. 1963: Bioenergetics and the determination of home range size. Amer. Natur., 97: 133-140.

38. McNab B. K., 1980. Food habits, energetics, and the population biology of mammals. Amer. Natur., 116: 106-124.

39. Myers K. \& Mykytowycz R., 1958: Social behaviour in the wild rabbit. Nature, 181: 1515-1516.

40. Orr R. T., 1940: The rabbits of California. Occas. Papers Calif. Acad. Sci., 19: $1-227$.

41. Pielowski Z. 1972: Home range and degree of residence of the European hare. Acta theriol., 17: 93-103.

42. Rausch R. L. 1961. Notes on the collared pika, Ochotona collaris (Nelson), in Alaska. Murrelet, 42: 22-24.

43. Schoener T. W., 1968: Sizes of feeding territories among birds. Ecology, 49: $123-141$.

44. Southern, H. N. 1940. The ecology and population dynamics of the wild rabbit, Oryctolagus cuniculus (L). Ann. Appl. Biol., 27: 509-526.

45. Southern H. N. \& Thompson H. V., 1964: Order Lagomorpha. [In: "The handbook of British mammals", 1st edition, H. N. Southern, ed.]. Blackwell Sci. Publ: 249-262. Oxford.

46. Swihart R. K. 1984: Body size, breeding season length, and life history tactics of lagomorphs. Oikos, 43: 282-290.

47. Swihart R. K. \& Slade N. A., 1985: Testing for independence of observations in animal movements. Ecology, 66: 1176-1184.

48. Terrel T. L. 1972. The swamp rabbit (Sylvilagus aquaticus) in Indiana. Amer. Midland Natur., 87: 283-295.

49. Trent T. T. \& Rongstad O. J., 1974: Home range and survival of cottontail rabbits in southwestern Wisconsin. J. Wildl. Manage., 38: 459-472.

50. Turner F. B., Jennrich R. I. \& Weintraub J. D., 1969: Home ranges and the body size of lizards. Ecology, 50: 1076-1081.

51. Vaughan T. A. 1972: Mammalogy. W. B. Saunders Co: 1-463. Philadelpia.

52. Vohries C. T. \& Taylor W. P., 1933: The life histories and ecology of jack rabbits, Lepus alleni and Lepus californicus ssp., in relation to grazing in Arizona. Ariz. Agric. Exp. Stn. Tech. Bull. No. 49: 465-587.

53. Watson A. \& Hewson R., 1973: Population densities of Mountain hares Lepus timidus on western Scottish and Irish moors and on Scottish hills. J. Zool., 170: $151-159$.

54. Watson A., Hewson R., Jenkins D. \& Parr R., 1973: Population densities of mountain hares compared with red grouse on Scottish moors. Oikos, 24: $225-230$.

55. Western D. 1979: Size, life history and ecology in mammals. African J. Ecol. 17: $185-204$

Accepted, September 3, 1985. 
Robert K. SWIHART

\section{ZALEŻNOSC WIELKOSCI AREAEU OD CIĘŻARU CIAŁA U ZAJĘCY I KROLIKOW (LEPORIDAE)}

\section{Streszczenie}

Dane zebrane dla 12 gatunków zajęcy i królików z rodzajów Sylvilagus, Lepus i Oryctolagus (Tabela 1) wskazują, że rozmiar areału zależy wykładniczo od ciężaru ciała (Fig. 1A) oraz w dużym stopniu od wskaźnika pokrywania się arealów $S$, który jest dodatnio skorelowany z ciężarem ciała (Fig. 1B). Sredni areał osobnika zależy również od jego wymagań energetycznych.

Ponieważ ekologia behawioralna jest czynnikiem determinującym rozmiar areału u wielu ssaków, badania porównawcze muszą brać pod uwagę wpływ interakcji między osobnikami tego samego gatunku i różnice środowiskowe zarówno w wielkości areałów jak i w indywidualnych sposobach użytkowania przestrzeni. 